Georgia State University

ScholarWorks @ Georgia State University

\title{
The Impact of Incentives to Recruit and Retain Teachers in "Hard- to-Staff" Subjects
}

\section{Li Feng}

Texas State University, Li.Feng@txstate.edu

Tim R. Sass

Georgia State University, tsass@gsu.edu

Follow this and additional works at: https://scholarworks.gsu.edu/uwrg_workingpapers

\section{Recommended Citation}

Feng, Li and Sass, Tim R., "The Impact of Incentives to Recruit and Retain Teachers in "Hard-to-Staff" Subjects" (2017). UWRG Working Papers. 111.

https://scholarworks.gsu.edu/uwrg_workingpapers/111

This Article is brought to you for free and open access by the Usery Workplace Research Group at ScholarWorks @ Georgia State University. It has been accepted for inclusion in UWRG Working Papers by an authorized administrator of ScholarWorks @ Georgia State University. For more information, please contact scholarworks@gsu.edu. 


\section{W. J. Usery Workplace Research Group Paper Series}

Working Paper 2017-9-4

September 2017

\section{The Impact of Incentives to Recruit and Retain Teachers in 'Hard-to-Staff' Subjects}

Li Feng
Texas State University

Tim R. Sass

Georgia State University

\section{AndREW Young SchoOL}




\title{
The Impact of Incentives to Recruit and Retain Teachers in "Hard-to-Staff" Subjects"
}

\author{
Li Feng \\ Department of Finance and Economics \\ McCoy College of Business Administration \\ Texas State University \\ San Marcos, TX 78666 \\ Email: Li.Feng@txstate.edu
}

\author{
Tim R. Sass \\ Department of Economics \\ Andrew Young School of Policy Studies \\ Georgia State University \\ Atlanta, GA 30303 \\ Email: tsass@gsu.edu
}

September 9, 2017

\begin{abstract}
We investigate the effects of a statewide program designed to increase the supply of teachers in designated "hard-to-staff" areas, such as special education, math, and science. Employing a difference-in-difference estimator we find that the loan forgiveness component of the program was effective, reducing mean attrition rates for middle and high school math and science teachers by 10.4 percent and 8.9, respectively. We also find that the impact of loan forgiveness varied with the generosity of payments; when fully funded the program reduced attrition of special education teachers by 12.3 percent, but did not have a statistically significant impact when funding was substantially reduced. A triple-difference estimate indicates that a one-time bonus program also had large effects, reducing the likelihood of teachers' exit by as much as 32 percent in the short run. A back-of-the-envelope cost-benefit analysis suggests that both the loan forgiveness and the bonus program were cost effective.
\end{abstract}

\footnotetext{
*We wish to thank the staff of the Florida Department of Education's Education Data Warehouse for their help in obtaining and interpreting the data used in this study. We are grateful to Sandy Black, Leigh Linden, Mike Geruso, Rodney Andrews, Monica Deza, and other seminar participants at the University of Texas - Austin and the University of Texas - Dallas. We also wish to thank our discussant Matt Kraft and participants at the Association for Education Finance and Policy and the Society for Research on Educational Effectiveness Conferences. Jarod Apperson and Carycruz Bueno provided able research assistance. Funding for this research was provided by the U.S. Department of Education, Institute of Education Sciences under grant R305A110967. Any opinions or errors are solely attributable to the authors, however.
} 


\section{Introduction}

Many school districts in the United States experience chronic shortages of teachers in highneed areas such as special education, math, and science. While there have been limited attempts to offer salary premiums to teachers in hard-to-staff subject areas, differential pay by subject area is controversial, and the more common policy response has been to offer indirect compensation in the form of either ex-ante or ex-post educational subsidies. Despite their widespread use, little is known about the efficacy of programs that link scholarships or student loan repayment to the labor supply of teachers. In this paper, we analyze one of the longest running such programs, Florida's Critical Teacher Shortage Program (FCTSP), in order to gauge the efficacy of non-wage compensation schemes on teacher retention. We focus on the program's loan forgiveness component, which targeted early career teachers who were certified and taught in a set of designated shortage areas. Eligible teachers could have up to $\$ 10,000$ in student loan debt repaid if they continued to teach in high-need subjects. In addition, we investigate the impact one-time retention bonuses of up to $\$ 1,200$ that were offered to Florida teachers in specific subjects and grade levels. By comparing the impacts of the two policies on teacher attrition, we are able to gauge the efficacy of loan forgiveness relative to more direct monetary compensation.

As described in more detail below, the FCTSP began in the mid-1980s and continued for over 20 years, finally being terminated by the Florida legislature in 2011 . Over that span, there were numerous changes in the particular subject areas covered and substantial variation in funding for the program. The discrete changes in subject area coverage from one year to the next, large and abrupt changes in funding, as well as the sudden termination of the loan forgiveness program can be viewed as plausibly exogenous events that can be used to identify the effects of varying compensation on retention of teachers in high-need areas. We utilize a difference-in-differences framework that exploits these inter-temporal changes to produce causal estimates of the impact of 
both the loan forgiveness and bonus programs on retention of teachers in Florida public schools. We find that loan forgiveness and targeted bonuses can both substantially reduce teacher attrition in high-need areas, although bonuses appear to have a larger impact in the short-run. We then translate these retention effects into estimated impacts on the steady state distribution of teacher experience and conduct a rough cost-benefit calculation; both loan forgiveness and bonuses appear to be cost effective policies.

Before delving into the analysis, we begin with a general discussion of the teacher shortage problem, its root causes, and the menu of options available to policy makers. This is followed by a detailed description of the FCTSP and associated teacher retention bonuses in Florida. We then provide a summary of the existing evidence on loan forgiveness, differential pay, and bonus programs for teachers. We subsequently describe our data and empirical methods before presenting our findings and discussing their implications.

\section{The Teacher Shortage Problem and Potential Solutions}

While concern is frequently expressed about shortages of teachers in general, school staffing problems are typically concentrated in certain subject areas, such as secondary math and science, special education, and foreign languages. Teachers with transferable skills that are valued in other occupations, such as math and science teachers with technical skills, or teachers with knowledge of foreign languages, have relatively high opportunity costs and thus would be expected to garner a wage premium in an unfettered market. Likewise, teachers working in challenging or stressful situations, such as special education teachers, would normally command a compensating wage differential. However, the wages of public school teachers are typically determined by fixed salary schedules that vary only by years of experience and educational attainment. As a result, schools find it difficult to attract and retain high-quality teachers in these 
areas. Ingersoll and Perda (2009) find that roughly three to four times as many secondary schools report significant difficulty in filling positions in mathematics, special education, and science relative to English or social studies. Similarly, Billingsley, Fall, and Williams (2006) report that high percentages of uncertified new special educators enter teaching each year. In Florida, the percentage of new hires in special education, English for Speakers of Other Languages (ESOL), and math and science who are not certified in their subject typically far exceeds that of elementary education teachers (Florida Department of Education, 2008).

The problems with staffing such "high-need" areas are exacerbated in urban schools and schools serving high proportions of low-income students since (given fixed salary schedules) teachers tend to migrate toward schools with high achieving students from affluent backgrounds and avoid schools serving primarily minority students, low-achieving students, and students with disciplinary problems (Lankford, Loeb, \& Wyckoff, 2002; Hanushek, Kain, \& Rivkin, 2004; Boyd, et al., 2005; Imazeki, 2005; Scafidi, Sjoquist, \& Stinebrickner, 2007; Feng, 2009). Further, filling positions in high-need areas with unqualified personnel may worsen supply problems in the long run. Miller, Brownell, and Smith (1999) find uncertified special education teachers are less likely to stay in their positions and attrition rates among beginning teachers with minimal preparation is twice as high compared to those with more extensive preparation (Boe, Cook, \& Sunderland, 2006).

Given the supply curve for teachers is upward sloping (Falch, 2010, Wolter, \& Denzler, 2003) and wage increases have been shown to boost teacher retention (Hendricks, 2014), the most obvious solution to staffing problems in "high-need" areas would be to offer higher wages. The market-clearing wage will depend on subject-area training requirements, alternative wages outside of teaching, and working conditions within classrooms and schools. Consequently, the requisite 
wage premium to avoid shortages will likely vary by field. Both teacher labor unions and individual teachers have tended to resist differential pay systems, however. As a result, instances where teacher salaries vary consistently by subject area are relatively rare. Only a small number of school districts offer permanent salary differentials for teachers in high need-need subjects (Martin, 2007). The State of Georgia allows new math and science teachers to start at a pay rate equivalent to teachers with five years of experience, but the differential declines over time and is eliminated at the end of five years (Griffin \& McGuire, 2015).

As an alternative to explicit permanent salary differentials, a variety of differentialcompensation schemes designed to attract and retain teachers in hard-to-staff subjects have been employed. Loan forgiveness, whereby some or all of a teacher's student loan debt is paid off if they continue to teach in a particular subject area or type of school, is probably the most common strategy. At least 40 states offer some kind of loan forgiveness or ex-ante scholarship program for teachers, although the specifics of the programs vary considerably (American Federation of Teachers, 2009). In addition, the U.S. Department of Education will forgive up to $\$ 17,500$ of debt for highly qualified math, science, or special education teachers who have taught continuously for five years in a school serving primarily low-income students (Martin, 2007). One-time "signing bonuses" or moving expense reimbursements for new recruits, although less common, have been used in a number of states such as California, Mississippi, and Virginia (Martin, 2007). Finally, some school districts have offered retention bonuses for short periods of time, and North Carolina offered bonuses to math, science, or special education teachers in schools serving primarily lowincome students for three years (Clotfelter, Glennie, Ladd, \& Vigdor, 2008).

While more palatable politically, the temporary nature of alternative incentive schemes may limit their efficacy in combating teacher shortages. Signing bonuses or reimbursements for 
moving expenses would only affect initial employment decisions of prospective teachers, but would not impact the relative costs and benefits of remaining a teacher. Likewise, loan forgiveness programs would only alter the labor market decisions of teachers who have outstanding student loan debt and have not yet received the maximum allowed amount of loan forgiveness. Although retention bonuses should affect short-term employment choices of teachers, to the extent the retention bonuses are viewed as temporary, they will have limited impacts on the long-run supply of teachers since they will have only modest effects on the present value of life-time earnings.

\section{Program Details}

The Florida Critical Teacher Shortage Program (FCTSP) was established in 1984 by the Florida Legislature to increase the supply of teachers in particular certification areas. Awards were made to qualifying teachers beginning in 1986/1987 and continued through 2009/2010, after which the Florida Legislature discontinued funding for the FCTSP. ${ }^{1}$ The FCTSP had two primary components: a tuition reimbursement program and a loan forgiveness program. Annual spending on the program averaged over three million dollars per year, with more than 90 percent of funds allocated to the loan forgiveness component.

The tuition reimbursement program was designed primarily to encourage existing teachers to become certified in a designated critical shortage subject area. To qualify, an individual had to have been employed by a Florida public school during the academic year and taken courses leading to certification or an advanced degree in a critical shortage area. To receive reimbursement for a course, the teacher had to have passed the course with a minimum grade of 3.0 on a four-point scale. In the tuition reimbursement program eligible teachers could receive payments of up to $\$ 78$

\footnotetext{
${ }^{1}$ Funding for both programs was eliminated by the 2011 Legislature, meaning the last cohort of teachers to receive awards were those who applied in the 2009/10 school year. See Florida CS/HB 7087, 2011 Legislative Session for more detail.
} 
per credit hour, for a maximum nine hours per award year or $\$ 702$ per year. The maximum total amount eligible applicants could receive was $\$ 2,808$ for up to 36 credit hours. An initial analysis showed that actual payouts were modest, averaging only $\$ 152$ per recipient. Further, two years prior to receiving tuition reimbursement, over two-thirds of eventual recipients were already certified in a critical shortage area, suggesting the program was primarily subsidizing existing teachers in critical shortage areas rather than inducing teachers to change subject areas. We therefore focus the present analysis on the loan forgiveness component, which had substantially higher monetary inducements for teachers.

The loan forgiveness program enhanced the compensation of eligible Florida teachers by repaying student loans if they continued teaching in a designated critical shortage area. The program targeted teachers who recently completed an undergraduate or graduate degree and were in their first year of teaching in a critical shortage area in a public school. To be eligible, a teacher had to have taught for at least 90 days in a critical shortage area and possess certification in that area. Initial applications had to be made at the end of their first year teaching in the relevant critical-shortage area. ${ }^{2}$ Shortage areas were typically announced well in advance (typically six to eight months prior to the start of the academic year). Applications had to be submitted by early July, based on applicants' teaching and certification status in the just-completed school year. Payments were typically made by the end of September.

Annual awards were prorated based on the number of eligible applicants and the total appropriation provided by the Legislature. For undergraduate loans, the maximum allowable award was $\$ 2,500$ dollars per year; for graduate loans, the maximum was $\$ 5,000$ per year. Awards could be received for a maximum of four academic years or a total disbursement of $\$ 10,000$,

\footnotetext{
${ }^{2}$ See 2002 Florida Statutes 1009.58 (tuition reimbursement) and 1009.59 (loan forgiveness) and Florida Administrative Code 6A-20.012 (tuition reimbursement) and 6A-20.013 (loan forgiveness).
} 
whichever came first. ${ }^{3}$ Actual compensation varied annually with the number of applicants and the legislative appropriation. Funding for the programs was relatively stable until 2002, with loan forgiveness payouts averaging $\$ 2,000$ to 3,000 per teacher. The 2002 Legislature slashed funding for the program, resulting in a nearly 48 percent reduction in funding and a drastic decrease in payments per teacher. Annual numbers of participants and average payments for the loan forgiveness program are provided in Figures 1 and 2. The drop in funding led to an increase in the number of loan forgiveness recipients as payments were spread out over more years; the number of initial recipients stayed relatively constant after the cut in funding.

The FCTSP legislation required the Florida State Board of Education to identify critical teacher shortage areas each year. The Florida Commissioner of Education provided a list of recommended areas to the board, based on: (i) current vacancies in the discipline, (ii) positions filled by teachers lacking proper certification in the relevant field, (iii) the projected supply of future graduates in the relevant area from state approved teacher preparation programs. Thus, the designated shortage areas changed over time. For example, middle and secondary math was a designated shortage area from 1984/1985 through 1992/1993; it was off the list of shortage areas from 1993/19994 to $1999 / 2000$, then was placed back on the list in 2000/2001. A matrix of covered subjects by year is provided in Table 1.

In addition to the long-standing loan forgiveness and tuition reimbursement programs, the 2000 Florida Legislature appropriated $\$ 60$ million for one-time recruitment and retention bonuses. To receive a bonus, a teacher had to be a full-time middle or high school classroom teacher certified and teaching foreign languages, science, math, or exceptional student education (special education

\footnotetext{
${ }^{3}$ In the individual-level award data we observe approximately 20 percent of loan forgiveness recipients receiving payments for five years or more. It is likely that most of these extended payment periods are due to teachers receiving loan forgiveness for both an undergraduate degree and a graduate degree. In fact, nearly 15 percent of loan forgiveness recipients received payments for both undergraduate and graduate loans.
} 
and gifted). Retention bonuses, which were capped at $\$ 1,200$, were for teachers who had taught in one of the designated subjects during the 1999/2000 school year, received a favorable performance appraisal, and agreed to continue teaching in one of the designated areas during the 2000/2001 school year. Recruitment bonuses were for teachers who were employed by a district for the first time in the 2000/2001 school year. Districts had discretion over the form of recruitment bonuses. For example, they could be used to cover moving expenses or to purchase a laptop computer. Like the retention bonuses, the payments were capped at $\$ 1,200$ per teacher. $^{4}$

The 2001 Florida Legislature also allocated $\$ 152$ million for recruitment and retention bonuses equal to $\$ 850$ per teacher. Unlike the bonus program in 2000 , the retention bonuses were available to all teachers who had taught during the 2000/2001 school year, irrespective of grade level or subject. Similarly, the signing bonuses were available to all new teachers. ${ }^{5}$

\section{Literature Review}

Although loan forgiveness is among the most common teacher incentive schemes, there is no prior research on the impact of loan forgiveness on either the supply of new teachers into targeted fields or targeted schools or on the retention of existing teachers in these areas. There is evidence that loan forgiveness programs in medicine have helped to retain physicians in rural and medically underserved areas (Pathman et al., 2004). However, loan forgiveness programs were shown to be less effective in attracting students into public interest law than tuition waivers of equivalent value (Field, 2009).

The extant literature on pay differentials for teachers working in hard-to-staff subjects or schools is similarly thin. Only one rigorous study of subject-area differential pay exists: an

\footnotetext{
${ }^{4}$ See Florida Department of Education (2000).

${ }^{5}$ Florida Department of Education (2001).
} 
analysis of an $\$ 1,800$ per year retention bonus paid to existing North Carolina teachers (Clotfelter, et al., 2008). The North Carolina program was a combination of subject-area and school-type differential pay. To qualify, teachers had to be certified in math, science, or special education and be working in middle and high schools that were serving primarily low-performing or low-income students. The $\$ 1,800$ bonus was equivalent to about four to five percent of the average pay of teachers in North Carolina. Clotfelter, et al. (2008) adopt a difference-in-difference-in-difference strategy to compare teachers before and after the implementation of the program, eligible teachers with ineligible teachers, and teachers in eligible schools with those in ineligible schools. Despite some problems in making teachers aware of the program, the targeted salary increases were sufficient to reduce turnover rates by 17 percent.

There are also three rigorous studies of the effects of programs designed to increase the supply of teachers in high-need schools. Steel, Murnane, and Willett (2009) study a California program that offered a $\$ 20,000$ bonus to a select group of new teachers that agreed to teach in high-need schools. They find the program increased the likelihood that academically talented teachers would begin teaching in low-performing schools, but the program had no effect on later retention. Glazerman, et al. (2013) conduct an experimental analysis of the "Teacher Transfer Initiative," a federally funded initiative that offered $\$ 20,000$ in incentives for high-quality teachers to teach in low-achieving schools for two years. While teachers who transferred had a positive impact on student test scores, only a small fraction of eligible teachers were induced to participate in the program. Falch $(2010,2011)$ studies a decade-long bonus program for Norwegian teachers. The program paid a wage premium of about 10 percent to teachers in schools with chronic staffing shortages. The program was effective, reducing the likelihood of voluntary departures by about six percentage points. 


\section{Data}

Data on individual-level payments to teachers were provided by the Florida Department of Education's Office of Student Financial Assistance (OSFA). Although awards began in 1986/1987, we could only obtain individual-level data on loan forgiveness from 1996/1997 forward. Prior to 2002/2003, the loan forgiveness data did not distinguish between payments for undergraduate and graduate loans, nor did they distinguish between initial awards and renewals. Thus, for the first year of forgiveness data (1996/1997) we do not know whether payments made in that year were for initial awards or renewals.

Data for the universe of Florida public school teachers from 1995/1996 through 2012/2013 was obtained from the Florida Department of Education's Education Data Warehouse. These data include demographic characteristics, educational attainment, experience, certifications held, and classes taught for each individual teacher. Since the data are statewide, we can determine when a teacher stops teaching in the Florida public schools.

Data for teachers are linked to the students they teach in each classroom, so we can determine the characteristics of students a teacher instructs. The data also contain test scores for individual students. The State of Florida administered the "Sunshine State Standards" Florida Comprehensive Achievement Test (FCAT-SSS) for Math and Reading in each of three to ten beginning in school-year 2000/2001 and ending in 2010/2011. ${ }^{6}$ We can therefore compute valueadded measures of the impact of individual teachers in these subjects for each of the academic years $2001 / 2002$ to $2010 / 2011$.

\footnotetext{
${ }^{6}$ Beginning in 2010/2011, the state adopted a new test, dubbed the FCAT 2.0. Scores for the first administration of the FCAT 2.0 were retrofitted to be comparable to the original FCAT scores. The Florida Department of Education does not deem the FCAT 2.0 scores from subsequent years to be comparable to those from the original FCAT, however.
} 


\section{Methods}

As described above, the loan forgiveness program primarily targeted early-career teachers who were already teaching and certified in a designated subject area. While the loan forgiveness program may have had some effect on the supply of new teachers in the long run, the most immediate effect was on retention of existing teachers. ${ }^{7}$ We exploit the fact that teachers had to be both eligible for the loan forgiveness program and the program had to be available in a given year in order to receive payment and estimate a difference-in-difference model of the duration of teaching in Florida public schools. To capture a teacher's entire employment history, we limit the analysis to teachers who are observed in their first year of teaching in Florida and had not taught out-of-state for more than five years.

The difference-in-difference approach compares changes in teacher retention among eligible teachers when a subject is placed on the critical shortage list with corresponding changes in retention over time for ineligible teachers. The model includes both controls to account for time-invariant differences in retention across subject areas and year indicators to control for general trends in teacher labor markets conditions that may vary over time. However, the approach could produce biased estimates of program effects if trends in the alternative wages of teachers vary by subject area and those subject-specific labor market trends are correlated with the timing of a subject being designated as a critical-need area. Given the variation in the timing of criticalneed areas across subjects and the abrupt and relatively permanent within subject changes in designation (see Table 1), such a correlation seems unlikely, however. Further, as noted by

\footnotetext{
${ }^{7}$ An analysis of long-run supply effects is difficult to conduct due to two data limitations. First, the Florida Education Data Warehouse only includes information on post-secondary students who attend public colleges and universities in Florida; therefore, we cannot track the number of students who obtain education degrees in private post-secondary institutions. Second, for students in public colleges and universities, we only have course taking and major information for the period 2000/2001 through 2011/2012. The readily identifiable critical-need subject areas (math, science, special education, and ESOL) were each designated shortage areas throughout this time period, thereby eliminating the possibility of a difference-in-differences analysis.
} 
Chingos and West (2012), relatively few teachers who exit public school teaching move to jobs outside of the educational sector, reducing the likelihood of bias coming from inter-temporal fluctuations in labor supply and demand conditions in other industries.

Formally, we estimate a Cox proportional hazard model can be represented as:

$h(t)=h_{0}(t) \exp \left(\beta_{1 j} E_{i j}^{L F}+\beta_{2 j} Z_{t j}^{L F}+\beta_{3 j}\left(E_{i j}^{L F} \times Z_{t j}^{L F}\right)+\gamma\left(X_{i t}\right)+\pi\left(D_{k}\right)\right)$

where $\lambda\left(t_{i}\right)$ is the probability that a teaching spell ends at the close of period $t$ for teacher $i$, conditional on that spell lasting through period t. ${ }^{8} E_{i j}^{L F}$ is a set of indicators for teachers who ever meet the loan forgiveness criteria of being certified and teaching in subject $j$, where $j=1$ to $N$, and $\mathrm{N}$ is the number of ever-covered subjects. ${ }^{9} Z_{t j}^{L F}$ is a set of indicators that signify the loan forgiveness program was in place in year $t$ for subject $\mathrm{j}$. $\mathrm{X}_{\mathrm{it}}$ is a vector of teacher and school characteristics that typically impact teacher attrition decisions (e.g. demographic characteristics of students taught, class size, students' prior behavior, students' prior achievement levels, teacher gender, teacher race/ethnicity, teacher experience, and base salary). Also included in $\mathrm{X}$ are a set of year indicators to capture any unobserved time-varying factors affecting teacher labor market decisions. $D_{k}$ is a vector of indicators for teachers teaching in a given district k. They account for any district-level factors that might be correlated with the likelihood that a teacher receives loan forgiveness and the probability of exit. The set of coefficients $\beta_{1 \mathrm{j}}$ represent the difference in the hazard rates between ever-eligible teachers (those certified and teaching in each subject $\mathrm{j}$ ) and never-eligible teachers. ${ }^{10} \beta_{2 j}$ represents the impact of being in a year in which a subject is covered

\footnotetext{
${ }^{8}$ We determine the end of a spell based on whether a teacher is teaching in a Florida public school in period $t+1$. Only a teacher's first teaching spell is considered; all exits are treated as permanent.

${ }^{9}$ By comparing ever-eligible teachers to never-eligible teachers the categorization of teachers does not change over time. However, treatment depends on both being an "ever-eligible" teacher and being in a year in which the teacher's subject area is a designated critical shortage area, i.e. $\left(E_{i j}^{L F} \times Z_{t j}^{L F}\right)$. Thus, treatment is time dependent.

${ }^{10}$ When estimating the model for each subject, we exclude teachers who are ever eligible in another covered subject.
} 
by the loan forgiveness program (both designated a critical-need area and the loan forgiveness program is in existence for that subject). The coefficients of interest are $\beta_{3 j}(j=1, N)$. These coefficients represent the effect of being eligible for the loan forgiveness program in subject $j$ and being in a year in which the program was in effect for the given subject. $\beta_{3 j}$ therefore represents the difference-in-difference estimate of the impact of the loan forgiveness program on the exit hazard in subject $\mathrm{j}$. While we observe both teaching assignments and certification status of teachers in each year, we do not know whether they possessed any student loan debt to be forgiven. The estimated impact, $\beta_{3}$, therefore should be interpreted as the impact of the "intent to treat."

The effects of the one-time retention bonuses can similarly be analyzed in the context of the Cox proportional hazard model. Recall that the 2000 retention bonus was limited to teachers who taught in a designated set of critical-need subjects at the middle and high school level in the 1999/2000 school year. Let $S_{i}^{B}$ be an indicator for teachers who ever met the retention bonus criteria of being certified and teaching in the set of designated subject areas. The variable $G_{i t}^{B}$ indicates teachers teaching middle and high school classes, and $Z_{t}^{B}$ is an indicator for the single year the program was in effect. Combining these variables with the loan forgiveness program factors into a single hazard model yields: ${ }^{11}$

$$
\begin{aligned}
h(t)= & h_{0}(t) \exp \left(\beta_{1 j} E_{i j}^{L F}+\beta_{2 j} Z_{t j}^{L F}+\beta_{3 j}\left(E_{i j}^{L F} \times Z_{t j}^{L F}\right)+\gamma\left(X_{i t}\right)+\delta\left(D_{k}\right)+\right. \\
& \delta_{1 j} S_{i}^{B}+\delta_{2} G_{i t}^{B}+\delta_{3} Z_{t}^{B}+\delta_{4}\left(S_{i}^{B} \times G_{i t}^{B}\right)+\delta_{5}\left(S_{i}^{B} \times Z_{t}^{B}\right)+\delta_{6}\left(G_{i t}^{B} \times Z_{t}^{B}\right)+ \\
& \left.\delta_{7}\left(S_{i}^{B} \times G_{i t}^{B} \times Z_{t}^{B}\right)\right)
\end{aligned}
$$

\footnotetext{
${ }^{11}$ In the estimation of equation (2) some terms are redundant and thus drop out of the equation. Since the bonus subjects are all also loan-forgiveness subjects at one time, the term $\delta_{1 j} S_{i}^{B}$ is omitted from the estimated equation. Likewise, the term $\delta_{3} Z_{t}^{B}$ is omitted because it is coincident with the year 1999 indicator that is included in the $\mathrm{X}$ vector.
} 
The coefficient of interest for the year 2000 retention bonus program is $\delta_{7}$, the coefficient on the triple-interaction term. It represents the difference-in-difference-in-difference estimate of the impact of the retention bonus program on the exit hazard. We also estimate a variant of equation (2) that accounts for the drop in funding for the loan forgiveness program, beginning in 2001/2002. In this alternative specification, we divide the interaction term, $\left(E_{i j}^{L F} \times Z_{t j}^{L F}\right)$, into two components, $\left(E_{i j}^{L F} \times Z_{t j}^{L F-l o w}\right)$ and $\left(E_{i j}^{L F} \times Z_{t j}^{L F-h i g h}\right)$, where high represents the pre-2001/2002 period and low is the period 2001/2002 and later.

Unlike the year 2000 program, the retention bonus program in 2001 covered all teachers, regardless of their subject area or grade level. Therefore the terms $S_{i}^{B}$ and $G_{i t}^{B}$ would each equal one for all teachers, and all of the bonus-related terms in equation (2) would collapse to a single indicator for the 2000/2001 school year. Consequently, it is not possible to isolate the impact of the across-the-board retention bonus program offered in 2000; any effect of the year 2000 retention bonus program is subsumed in the year 2000 indicator contained in the $\mathrm{X}$ vector.

Besides the effects on aggregate supply of teachers to designated subject areas, the efficacy of the loan forgiveness programs also depends on how it affects the quality of teachers in criticalshortage-area subjects. If effective, the loan forgiveness program increases retention of teachers who meet the eligibility criteria, i.e. they are certified and teaching in a designated critical-need subject area. If such teachers had exited, a substantial portion would likely have been replaced with uncertified teachers since finding fully certified teachers in the designated subjects by definition is difficult. Thus, we compare the quality distribution of loan forgiveness recipients with teachers who did not receive loan forgiveness, but were ever certified and teaching in the same subject and with non-recipients teaching in the same subject who were never certified. Since achievement tests are administered in consecutive grades for only two subjects, math and reading, 
we can only compute value-added measures for teachers who are responsible for math or reading instruction. The critical-need subject with the most direct link to state assessments is middle and high school math. In addition, due to their large number, we also compare value added in math and in reading for special education teachers.

\section{Empirical Results}

\section{A. Summary Statistics}

Table 2 provides summary statistics for Florida K-12 teachers and their students. The data are broken down into four categories: (i) teachers who did not participate in either the loan forgiveness, tuition reimbursement, or bonus programs;(ii) teachers eligible for loan forgiveness (i.e. those who were certified and taught in a critical need area in the same year); (iii) loan forgiveness recipients; and (iv) recruitment-and-retention bonus recipients. Due to the nature of the loan forgiveness program, the recipients tend to be much younger and have less experience than non-recipients. Loan forgiveness recipients appear similar to loan forgiveness-eligible teachers, suggesting that self-selection of participants may be minimal. The makeup of classrooms appears to be similar across loan forgiveness recipients and non-recipients. The one exception is a higher number of disciplinary incidents per student. However, that is likely due to the fact that designated shortage areas are mainly in middle and high school subjects and special education, areas that tend to have a greater incidence of disciplinary problems than elementary school regular education classes. Over half of loan forgiveness recipients are special education teachers. The next most common areas are middle/high school math and science teachers, each making up about one-fifth of recipients (with some overlap).

Table 3 provides a tabulation of experience for first-time recipients of loan forgiveness. As expected, loan forgiveness primarily affects early-career teachers. Nearly three-fourths of first 
time loan forgiveness recipients are in their first two years of teaching, and nearly 90 percent are in their first four years of teaching when they receive their initial award.

\section{B. Patterns of Loan Forgiveness and Teacher Retention}

Descriptive evidence on the efficacy of the loan forgiveness program is provided in Figure 3, which plots Kaplan-Meier survival estimates of teaching in Florida public schools, broken down by whether or not a teacher ever received a loan forgiveness payment. In order to account for differences in attrition across subject areas, the sample is limited to teachers who were ever simultaneously certified and taught in a critical shortage area. For the first six years of teaching, loan forgiveness recipients are more likely to remain a public school teacher in Florida than nonrecipients. The survival rates are essentially equal in years seven and eight, and then the survival rate of non-recipients exceeds that of recipients in subsequent years. Recall that recipients can receive loan forgiveness for an undergraduate loan for up to four years, and the modal experience level of initial recipients is one year (i.e. teachers in their second year of teaching). The higher survival rates observed over the first six years of teaching are consistent with the loan forgiveness program reducing teacher attrition as long as recipients are receiving payments.

\section{Causal Evidence of Loan Forgiveness and Bonuses on Teacher Retention}

In Table 4 we present Cox Proportional Hazard model estimates of the determinants of exit from Florida public schools (equation 2). Estimates from four models are presented, each with varying numbers of controls in the $\mathrm{X}$ vector. ${ }^{12}$ In Model 1, which excludes any controls for the characteristics of teachers or the students they teach, we find that loan forgiveness significantly reduces the probability of exit for middle/high school science teachers ( 8.9 percent), middle/high school math teachers (10.4 percent), foreign language teachers (12.2 percent), and ESOL teachers

\footnotetext{
${ }^{12}$ For space considerations, we only present the estimates of the key interaction terms. Estimates of the full set of model coefficients are available upon request.
} 
(27.4 percent). The larger point estimates for foreign language teachers and ESOL teachers should be viewed with some caution, however, since these teachers each constitute a small share of loan forgiveness recipients (see Table 2). The estimates remain relatively constant as additional controls for teacher, and student characteristics are added to the model. Although the estimated hazard for the largest group of loan recipients, special education/gifted teachers, is less than one, it is statistically insignificant. ${ }^{13}$

The average base salary for teachers during the time period of analysis is approximately $\$ 35,000$, and the annual loan forgiveness payments to lenders averaged around $\$ 1,200$. Thus, the average loan forgiveness recipient experienced a roughly $3.4 \%$ increase in net pay. Given the estimated reductions in exit probabilities of 10.4 percent for middle and high school math teachers and 8.9 percent for middle and high school science teachers, this implies exit elasticities for middle and high school math and science teachers of -3.1 and -2.6 , respectively. These estimates are comparable to the estimated elasticity of turnover of -3 from an $\$ 1,800$ bonus payment in North Carolina (Clotfelter et al., 2008). They are also similar to the quit elasticity of -3.5 estimated from a targeted school-wide bonus for certified teachers in Norway (Falch, 2010; Falch, 2011).

For the year 2000 bonus program we find a large and statistically significant effect on the hazard ratio; the bonuses lead to a 32.2 percent reduction in the probability of exit. This finding is robust across all three specifications. Given this was a one-time bonus, the large estimated impact should be interpreted as a short-run effect and does not necessarily represent the impact on retention of a permanent salary differential across subjects. Put differently, the bonus may have

\footnotetext{
${ }^{13}$ We determine the subject area an individual is teaching in by the identity of the courses they teach. Special education teachers (the majority of program participants) who are assigned solely to work with students with disabilities in general education classes and do not teach any designated special education courses would not be classified as teaching special education. Such situations are rare, however.
} 
induced teachers to stay in the public school system an additional year, but may not have significantly affected long-run career plans.

We exploit the fact that the generosity of loan forgiveness abruptly dropped after 2000/2001 as an additional source of identifying variation by separating the interaction term in equation (2) into two parts, one for the high-payout era prior to 2001/2002 and another for the lowpayout period after 2000/2001. This can only be done for the two subject areas that span the two time periods, special education/gifted and ESOL. Results from estimating this alternative specification are given in Table 5.

The effect of the loan forgiveness program on the probability of exit for special education/gifted teachers in the high-payout period is now estimated to be between -10.1 and -12.3 percent (depending on the number of controls) and is statistically significant at better than the one percent level. During this high payout period, the average loan forgiveness amount is around $\$ 2,000$, which is equivalent to a 5.7 percent increase in net pay for the average teacher. The attrition reduction of 10.9 percentage points (from the model with all controls included) therefore translates into an exit elasticity of -1.9 for special education teachers. During the low payout period, the average loan forgiveness payment was only about $\$ 750$. This is equivalent to a two percent increase in net pay for a teacher with the average salary. We estimate the effect of this change in net salary on the exit probability of special education/gifted teachers to be small $(-0.5$ percent) and statistically insignificant.

For ESOL, the program effects are large and statistically significant in both the high and low-payout periods, though smaller in the low payout period. In the model with all controls, the estimated effect of loan forgiveness on the probability of exit for ESOL teachers is 42.1 percent in the high payout period and 24.5 percent in the low payout period. 
We argue that the timing of declaring a subject to be an area of "critical shortage" is uncertain and thus plausibly exogenous to teachers. However, once a subject area is placed in the critical-shortage category, it has kept that designation throughout our sample period (see Table 1). Thus, it is possible that once a subject is designated a critical shortage area, prospective teachers who intend to stay in the public school system for several years, and would hence benefit the most from loan forgiveness, could gravitate toward that subject. If this sort of selection into subject areas occurs, it could upwardly bias our estimates of the impact of loan forgiveness on teacher retention.

As a robustness check against this possible bias, we re-estimate the hazard model, limiting the analysis sample to new-teacher cohorts for two years on either side of a change in subject-area eligibility. Teachers entering just prior to a change in designation could not have anticipated the change, and teachers entering just after the change in designation would likely have been too far along in their college coursework to alter their major. Five subjects experienced a change in critical teacher shortage status during our estimation period, middle/high science in 2000/2001, middle/high math in 2000/2001, foreign languages in 2001/2002, middle/high English in $2008 / 2009$, and reading in 2002/2003. Given the timing of eligibility changes, we re-estimated the hazard model over four sets of new-teacher cohorts, 1998/1999 through 2001/02, 1999/2000 through 2002/2003, 2006/2007 through 2009/2010, and 2000/2001 through 2003/2004.

Results are presented in Table 6. Among the five subjects, the three in which loan forgiveness had statistically significant effects on teacher attrition in the full-sample analysis, science, math, and foreign languages, continue to be statistically significant in the restricted-cohort analysis. The point estimates are similar as well, suggesting that strategic subject-area selection by prospective teachers is not significantly biasing our results. 


\section{Teacher Quality}

Ultimately, the efficacy of loan forgiveness depends not only on the ability to attract and retain teachers in high-need subjects, but also the quality of the teachers who are enticed to become certified and teach (or induced not to leave). A causal analysis of the relationship between loan forgiveness and teacher effectiveness is challenging, however. Value-added can only be computed for 27 percent of teachers in our sample. Further, given that only math and reading exams were administered in grades three through ten, several critical shortage areas have few teachers in tested grades and subjects (e.g. foreign languages, middle/high school English, middle/high school science).

Given the data limitations, we only present descriptive evidence for the two critical shortage areas where value-added measures of teacher quality can be computed for a significant number of teachers: middle/high school math and special education. ${ }^{14}$ In Figures $4 \mathrm{~A}$ to $4 \mathrm{C}$, we present kernel density plots of teacher value-added in math for middle and high school math teachers and value added in both math and reading for special education teachers. The valueadded estimates are the estimated teacher fixed effects in a model of student achievement that includes the lagged test score, a vector of potentially time-varying student characteristics, classroom peer characteristics, time invariant student characteristics, and a vector of potentially time-varying school-level inputs. ${ }^{15}$ We compare recipients' value-added distribution to that of non-recipients teaching in the same subject to two comparison groups: non-recipients who were

\footnotetext{
${ }^{14}$ We attempted to estimate the hazard model of teacher exit over three sub-samples of teachers, those in the bottom quartile of the value-added distribution, those in the middle two quartiles and teachers in the top quartile. Given the small samples, loan forgiveness was only found to have significant effects on the probability of exit for top and bottom quartile special education teachers and top quartile ESOL teachers.

${ }^{15}$ Details on the construction of the value-added measures are provided in Feng and Sass (2017).
} 
ever simultaneously certified and taught in the same subject area and non-recipients who taught in the same subject area, but who were never certified.

In Figure 4A, we see that loan forgiveness recipients are of essentially equal quality to nonrecipients who are teaching and certified in middle/high school math. In contrast, middle and high school math teachers who are never certified are of much lower quality than loan forgiveness recipients. Figures $4 \mathrm{~B}$ and $4 \mathrm{C}$ provide similar comparisons for special education teachers in math and in reading, respectively. The differences are not as stark as for middle and high school math teachers. However, it is still the case that the value added for loan forgiveness recipients is generally comparable to that of non-recipients who also are certified and teaching in special education, whereas special education teachers who never become certified tend to have lower value added scores. ${ }^{16}$

\section{E. Student Achievement and Cost Effectiveness}

Our findings indicate that both loan forgiveness and short-term bonuses can substantially reduce teacher attrition in "difficult-to-staff” subjects like high school math and science and special education. Further, the beneficiaries of these programs appear to be at least as productive as nonrecipients who are certified and teach in the same subject areas.

The direct benefits of the program to students depend on how the program affects the equilibrium distribution of teachers. By reducing attrition, loan forgiveness, and retention, bonuses will increase average teacher experience, which in turn increases the average contribution of teachers to student achievement. In order to get rough estimates of the net benefit of loan

\footnotetext{
${ }^{16}$ The positive relationship between subject-area certification and teacher value added may appear atypical at first blush, given the general finding that teacher credentials are uncorrelated with teacher performance. However, much of the value-added literature is based on regular education teachers in elementary and middle school. Clotfelter, Ladd, and Vigdor (2010) find that in-subject certification is associated with higher student test scores in high school. Similarly, Feng and Sass (2013) find that teachers of special education courses who are certified in special education produce higher student test scores in both math and reading than do teachers who are not special-education certified.
} 
forgiveness and retention bonus strategies, we therefore first estimate the impacts or loan forgiveness and bonuses on the distribution of teacher experience and then translate change in teacher experience into expected impacts on student achievement. Finally, we translate student achievement into monetary gains based on recent estimates of the relationship between teacher quality and lifetime earnings.

To estimate the impact of the programs on the steady-state distribution of teacher experience, we adopt the methodology of Kane, Rockoff, \& Staiger (2008) and Hansen, Backes, \& Brady (2015). Using the results from Model 4 in Table 4 (and treating statistically insignificant effects as equal to zero), the weighted average reduction in the attrition rate from loan forgiveness is 6.3 percentage points. Applying this reduction in the attrition rate to the estimated attrition rates for non-loan forgiveness recipients (Figure 3) yields annual retention probabilities for teachers with and without the loan forgiveness program. From this, we can determine the steady state distribution of teacher experience with and without loan forgiveness.

The ultimate impact on teacher effectiveness depends on the returns to teacher experience. As noted in Table 2, the vast majority of loan forgiveness recipients taught special education, middle/high school math, and middle/high school science. We are aware of only two studies in the last decade that estimate within-teacher returns to experience for middle or high school math (Ladd \& Sorenson (2017) and Harris \& Sass (2011)) and a single study that separately estimates returns to experience for special education teachers at any grade level (Feng \& Sass (2013)). ${ }^{17}$ Using the average of the estimates for middle school math teachers from Ladd and Sorenson (2017) and from Harris and Sass (2011), which are quite similar, the increase in the steady-state value-

\footnotetext{
${ }^{17}$ Some recent studies of middle school teachers do not include teacher fixed effects and therefore may conflate returns to experience with differences in attrition across teachers of varying quality (e.g. Chingos and Peterson (2011)), and others only estimate returns over broad bans of experience (e.g. Papay and Kraft (2015)).
} 
added of teachers is only 0.003 standard deviations. The lower return to experience for special education teachers found in Feng and Sass (2013) suggests an increase in steady-state value-added of only 0.001 standard deviations. ${ }^{18}$ If we instead employ the weighted average reduction in the attrition rate of 13.7 percentage points from the era when the loan forgiveness program was fully funded (Table 5), the steady-state increase in value-added rises to 0.007 standard deviations for middle school math teachers and 0.002 for special education teachers. These estimates are in line with the 0.005 standard deviation estimated impact of North Carolina's bonus program reported by Clotfelter, et al. (2008). The one-time bonus program in Florida was estimated to reduce the attrition rate by 32.5 percentage points (Table 4), which translates to a 0.030 standard deviation increase in steady-state value added for middle school math teachers and a 0.008 increase for special education teachers.

Chetty, Friedman, and Rockoff (2014) estimate the present value of the gain per student from a one standard deviation increase in teacher value added to be $\$ 7,000$. Applying this value to our estimated changes in steady-state value added, the present value of the gain per student per grade for regular education teachers would range from $\$ 21$ to $\$ 49$ for the loan forgiveness program and $\$ 210$ per student per grade for the bonus program. Following the Clotfelter, et al. assumption of 100 students per teacher, the estimated single-year per-teacher benefit of the loan forgiveness program for regular education teachers is $\$ 2,100$ to $\$ 4,900$, and the one-time per-teacher benefit of the bonus program is $\$ 21,000 .{ }^{19}$ Given the per-teacher payouts for the loan forgiveness program peaked at $\$ 3,000$ in the fully funded era and dropped to a low of $\$ 550$ when funding was cut, these

\footnotetext{
${ }^{18}$ Feng and Sass (2013) do not include teacher fixed effects in their models, but do estimate returns to experience for both regular education and special education teachers. We therefore take the relative return to special education teachers from Feng and Sass (2013) and apply it to the within-teacher returns estimated in Harris and Sass (2011).

${ }^{19}$ Due to large variation in special education class sizes and lack the lack of evidence on the long-run effects increases in value-added for students with disabilities, we do not calculate per-teacher benefits separately for special education teachers.
} 
rough calculations suggest that the benefits to students exceeded the costs. The bonus program appears to have been even more cost-effective, generating benefits as high as $\$ 21,000$ per teacher from a maximum cost of $\$ 1,200$ per teacher for the bonus program.

While the estimated direct benefits to students from reducing teacher attrition are substantial, the total benefits may be even higher. By reducing the number of positions to be filled, school districts avoid the costs associated with hiring new teachers. Barnes, Crowe, and Schaefer (2007) estimate the costs of recruiting, hiring, and training a replacement teacher at $\$ 4,366$ to $\$ 17,872$, depending on location. Other, more difficult to quantify, possible effects include greater increases in teacher motivation/effort and investments in teaching-specific human capital.

\section{Summary and Conclusions}

Fixed pay scales coupled with variation in the opportunity cost of teachers and working conditions has led to chronic shortages of teachers in particular subject areas. Given opposition to pay differentials from teachers, the most common policy response has been to provide non-salary inducements for teachers to continue working in high-need areas. In this paper, we investigate the efficacy of one such program, Florida's Critical Teacher Shortage Program.

Exploiting variation in program coverage across time and across subjects, as well as variation in the generosity of payments, we find that the loan forgiveness component of Florida's Critical Teacher Shortage Program did have substantial positive effects on the likelihood an individual would remain in teaching. The impacts vary across subjects and depend in part on the magnitude of payments. Positive effects were found for four of seven subject areas (science, math, foreign languages, and ESOL). Positive effects were also found for the largest shortage-area category, special education/gifted teachers, although only when payments were relatively large. 
We also find that the $\$ 1,200$ one-time retention bonus offered to high school teachers in designated subject areas decreased teacher attrition in the targeted areas by as much as 25 percent.

Our findings suggest that educational subsidies, particularly ex-post loan forgiveness for early-career teachers, can be effective tools in promoting the retention of teachers in high-need areas. We find that relatively modest payments of $\$ 500$ to $\$ 1,000$ per year can reduce attrition in some high-need subjects, although in some subjects, such as special education, only payments on the order of $\$ 2,500$ per year appear effective. The efficacy of direct payments to teachers appears to be more cost effective than loan subsidies. A one-time bonus of \$1,200 reduced teacher attrition more than loan repayments of comparable magnitude. 


\section{References}

American Federation of Teachers (2009). Tools for teachers - loan forgiveness programs. Available at http://www.aft.org/tools4teachers/loan-forgiveness.htm.

Barnes, G., Crowe, E., \& Schaefer, B. (2007). The cost of teacher turnover in five school districts: a pilot study. National Commission on Teaching and America's Future, Arlington VA.

Billingsley, B., Fall, A., \& Williams, T. (2006). Who is teaching students with emotional disorders? A profile and comparison to other special educators. Behavioral Disorders, 31, 252-264.

Boe, E., Cook, L., \& Sunderland, R. (2006). Attrition of beginning teachers: Does teacher preparation matter? (Research Report No. 2006-TSDQ2). Center for Research and Evaluation in Social Policy, Graduate School of Education, University of Pennsylvania, Philadelphia, PA.

Boyd, D., Lankford, H., Loeb, S. \& Wyckoff, J. (2005). Explaining the short careers of highachieving teachers in schools with low-performing students. American Economic Review, 95, 166-171.

Chetty, R., Friedman, J. \& Rockoff, J. (2014). Measuring the impacts of teachers II: teacher value-added and student outcomes in adulthood. American Economic Review, 104, 2633-2679.

Chingos, M. \& West, M. (2012). Do more effective teachers earn more outside the classroom?. Education Finance and Policy, 7, 8-43.

Clotfelter, C., Glennie, E., Ladd, H., \& Vigdor, J. (2008). Would higher salaries keep teachers in high-poverty schools? Evidence from a policy intervention in North Carolina. Journal of Public Economics, 92, 1352-1370.

Clotfelter, C., Ladd, H., \& Vigdor, J. (2010). Teacher credentials and student achievement in high school: a cross-subject analysis with student fixed effects. Journal of Human Resources, 45, 655-681.

Falch, T. (2010). The elasticity of labor supply at the establishment level. Journal of Labor Economics, 28, 237-66.

Falch, T. (2011). Teacher mobility responses to wage changes: evidence from a quasi-natural experiment. American Economic Review: Papers and Proceedings, 101, 460-465.

Feng, L. (2009). Opportunity wages, classroom characteristics, and teacher mobility. Southern Economic Journal, 75, 1165-1190. 
Feng, L., \& Sass, T. (2013). What makes special-education teachers special? Teacher training and achievement of students with disabilities. Economics of Education Review, 36, $122-$ 134.

Feng, L., \& Sass, T. (2017). Teacher quality and teacher mobility. Education Finance and Policy, 12, 396-418.

Field, E. (2009). Educational debt burden and career choice: evidence from a financial aid experiment at NYU law school. American Economic Journal: Applied Economics, 1, 121.

Florida Department of Education (2000), Legislative Review: 2000. Tallahassee, FL.

Florida Department of Education (2001). Legislative Review: 2001. Tallahassee, FL:

Florida Department of Education, Office of Student Financial Assistance (various years). Annual report to the commissioner. Tallahassee, FL: Florida Department of Education.

Florida Department of Education, Office of Research and Evaluation (various years). Critical teacher shortage areas. Tallahassee, FL.

Florida Department of Education, Office of Research and Evaluation (2008). New hires in Florida public schools: Fall 1998 through Fall 2007. Tallahassee, FL.

Glazerman, S., Protik, A., Teh, B., Bruch, J., \& Max, J. (2013). Transfer incentives for highperforming teachers: final results from a multisite randomized experiment (NCEE 20144003). Washington, DC: National Center for Education Evaluation and Regional Assistance, Institute of Education Sciences, U.S. Department of Education.

Griffin, G. \& McGuire, L. (2015). Math and science salary incentives for teachers. Georgia Department of Audits and Accounts, Performance Audit Division, Special Examination Report No. 15-14.

Hansen, M., Backes, B., \& Brady, V. (2015). Teacher attrition and mobility during the Teach for America clustering strategy in Miami-Dade County Public Schools. CALDER working paper no. 139.

Hanushek, E., Kain, J. \& Rivkin, S. (2004). Why public schools lose teachers. Journal of Human Resources, 39, 326-354.

Harris, D. \& Sass, T. (2011). Teacher training, teacher quality and student achievement. Journal of Public Economics, 95, 798-812.

Hendricks, M. (2014). Does it pay to pay teachers more? Evidence from Texas. Journal of Public Economics, 109, 50-63. 
Ingersoll, R., \& Perda, D. (2009). The mathematics and science teacher shortage: fact and myth. CPRE Research Report \#RR-62.

Imazeki, J. (2005). Teacher salaries and teacher attrition. Economics of Education Review, 24, 431--449.

Kane, T., Rockoff, J., \& Staiger, D. (2008). What does certification tell us about teacher effectiveness? Evidence from New York City. Economics of Education Review, 27, 615-631.

Ladd, H., \& Sorenson, L. (2017). Returns to teacher experience: student achievement and motivation in middle school. Education Finance and Policy, 12, 241-279.

Lankford, H,, Loeb, S., \& Wyckoff, J. (2002). Teacher sorting and the plight of urban schools. A descriptive analysis. Educational Evaluation and Policy Analysis, 24, 37-62.

Martin, A. (2007). The use of diversified compensation systems to address equitable teacher distribution. Education Commission of the States, Issue Paper No. TQ-07-04.

Miller, D., Brownell, M., \& Smith, S. (1999). Factors that predict teachers staying in, leaving, or transferring from the special education classroom. Exceptional Children, 65, 201-218.

Pathman, D., Konrad, T., King, T., Taylor Jr., D., \& Koch, G. (2004). Outcomes of states' scholarship, loan repayment, and related programs for physicians. Medical Care, 42, 560-568.

Scafidi, B, Sjoquist, D., \& Stinebrickner, T. (2007). Race, poverty, and teacher mobility. Economics of Education Review, 26, 145-159.

Steele, J., Murnane, R., \& Willett, J. (2009). Do financial incentives help low-performing schools attract and keep academically talented teachers? Evidence from California. Journal of Policy Analysis and Management, 29, 451-478.

Wolter, S. \& Denzler, S. (2003). Wage elasticity of the teacher supply in Switzerland. IZA Discussion Paper No. 733. 
Figure 1: Number of Teachers Receiving Loan Forgiveness Payments by Year, 1986/87-2009/10

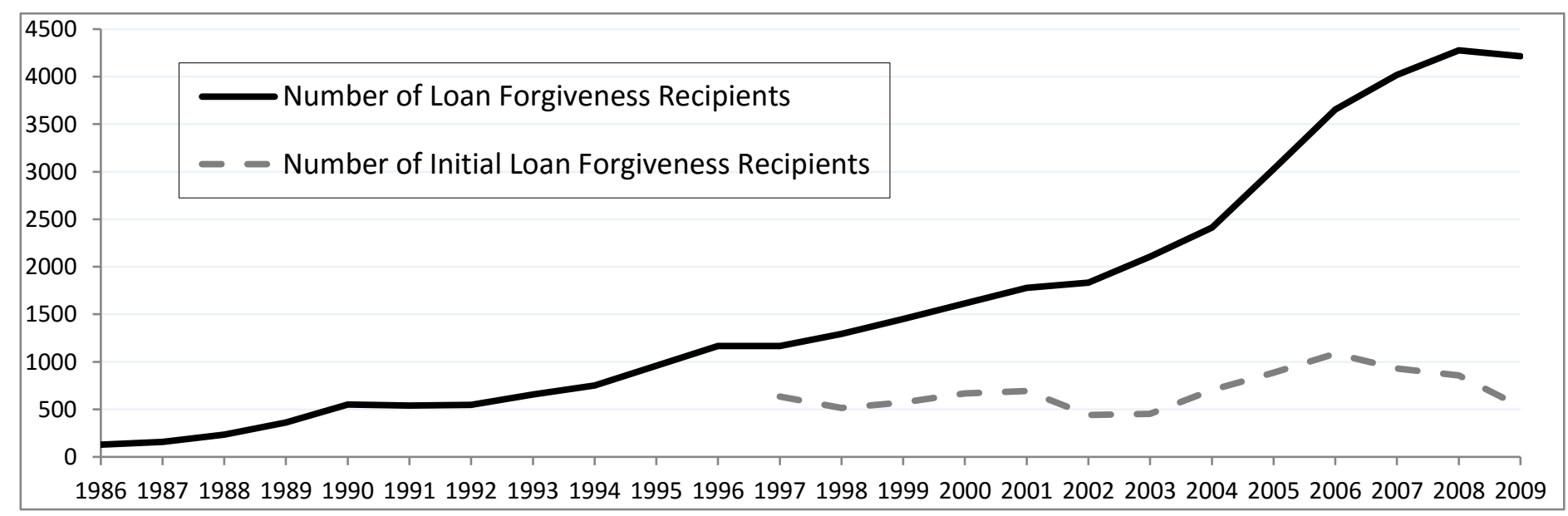

Source: Florida Department of Education, Office of Student Financial Assistance, Annual Report to the Commissioner (various years) and authors' calculations from individual-level data.

Figure 2: Average Payment per Recipient in Loan Forgiveness Program by Year, 1986/87-2009/10

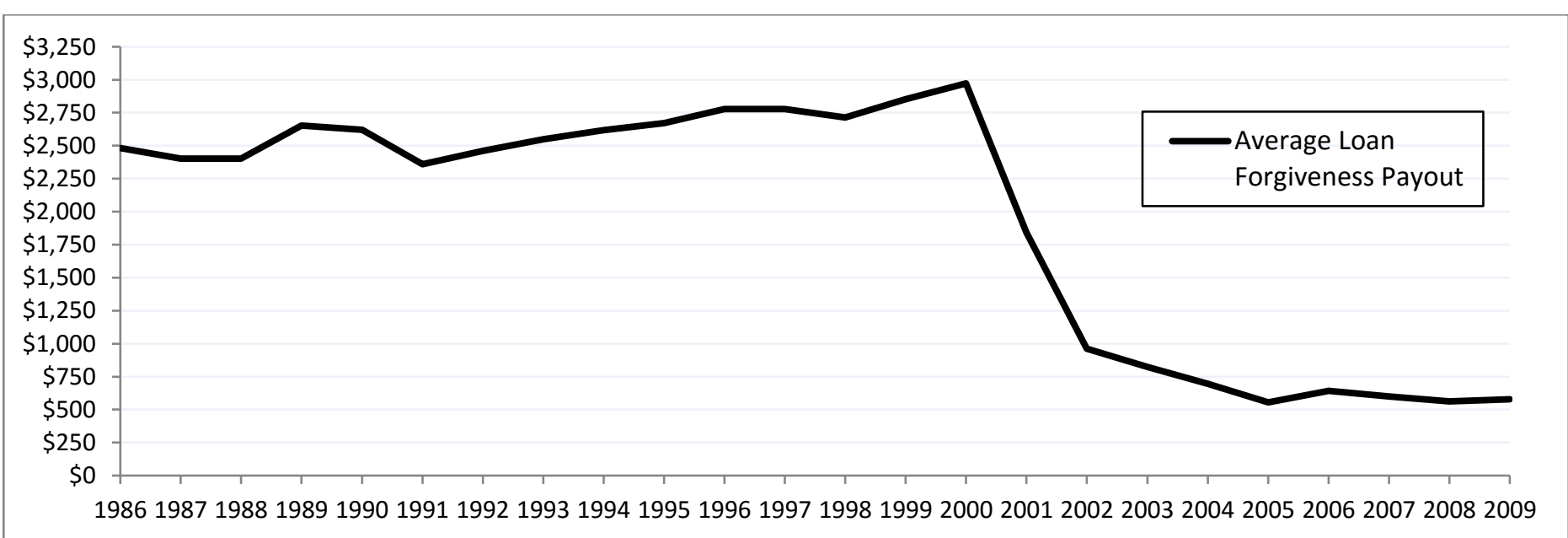

Source: Florida Department of Education, Office of Student Financial Assistance, Annual Report to the Commissioner (various years). 
Figure 3: Kaplan-Meier Survival Estimates of Teaching in Florida Public Schools Teachers who Were Ever Certified and Taught in Any Critical Shortage Area (Only Teachers Observed in Their First Year of Teaching)

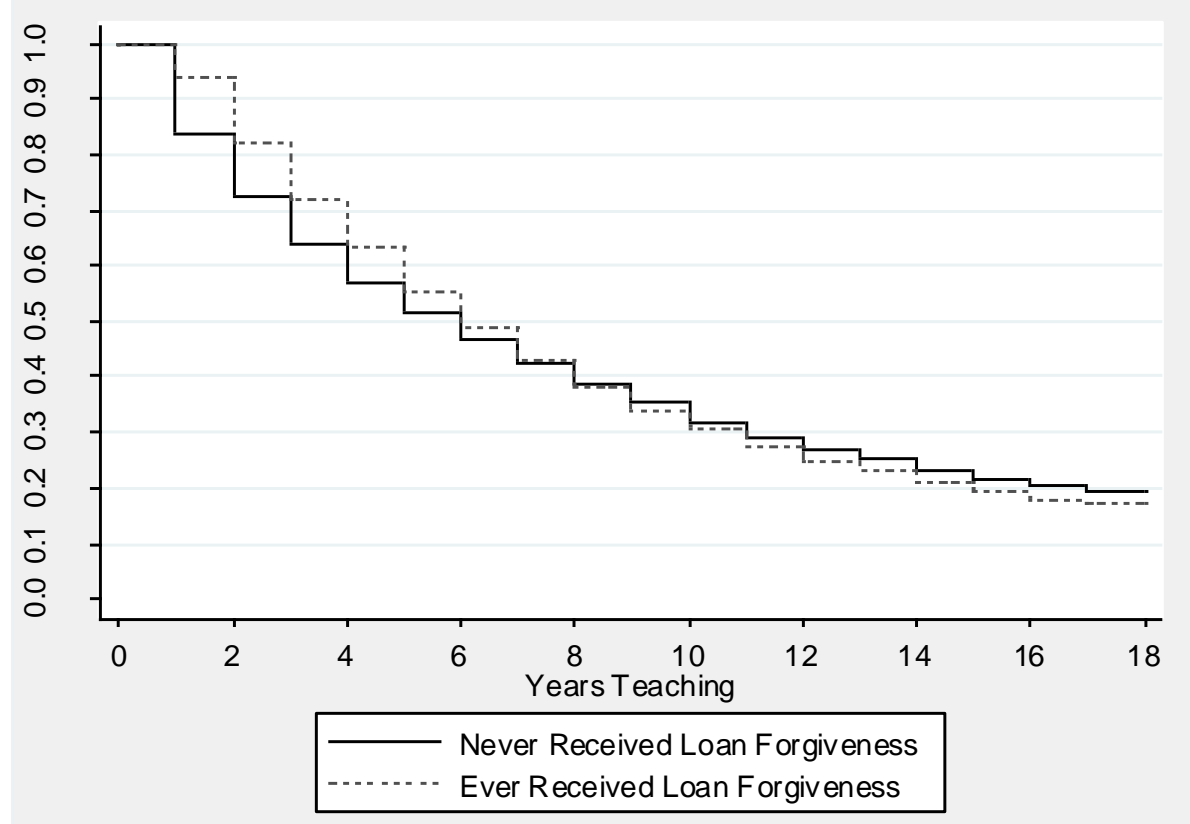

Note: excludes tuition reimbursement recipients.

Figure 4A: Kernel Density Plot of Math Value-Added Distribution by Loan Forgiveness Receipt - Middle and High School Math Teachers

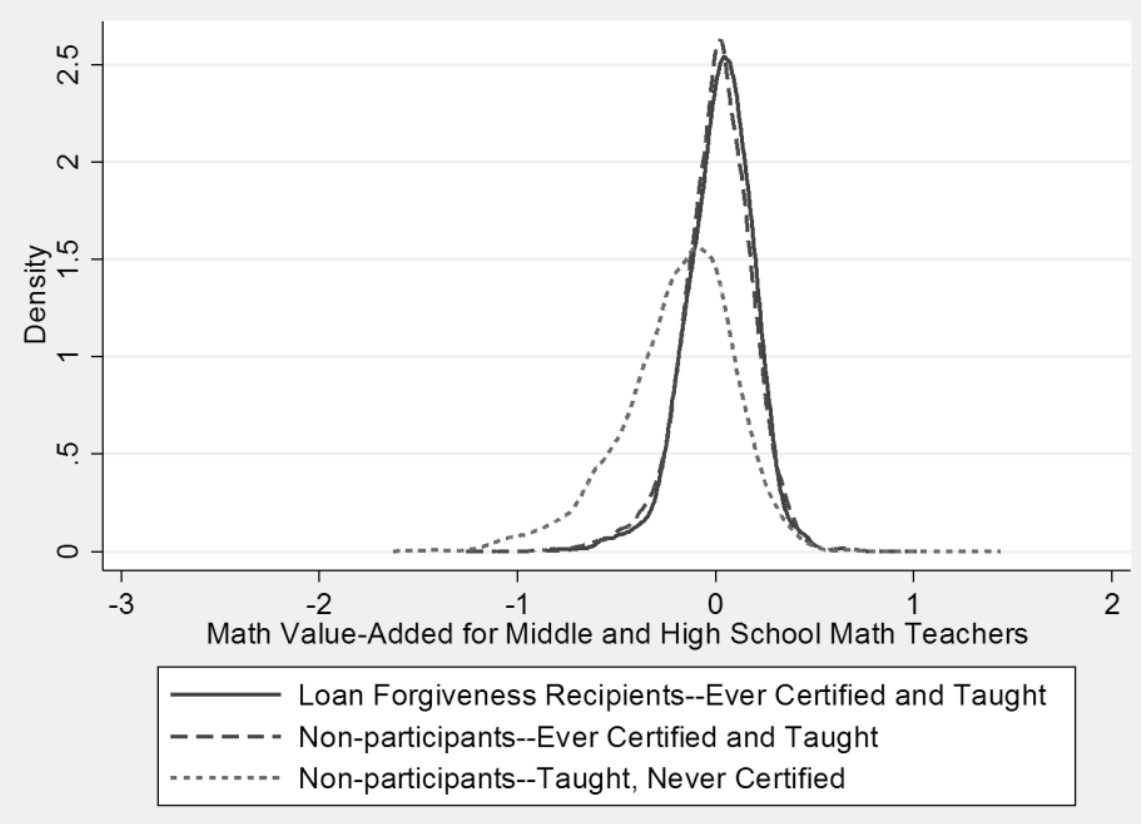


Figure 4B: Kernel Density Plot of Math Value-Added Distribution by Loan Forgiveness Receipt - Special Education Teachers

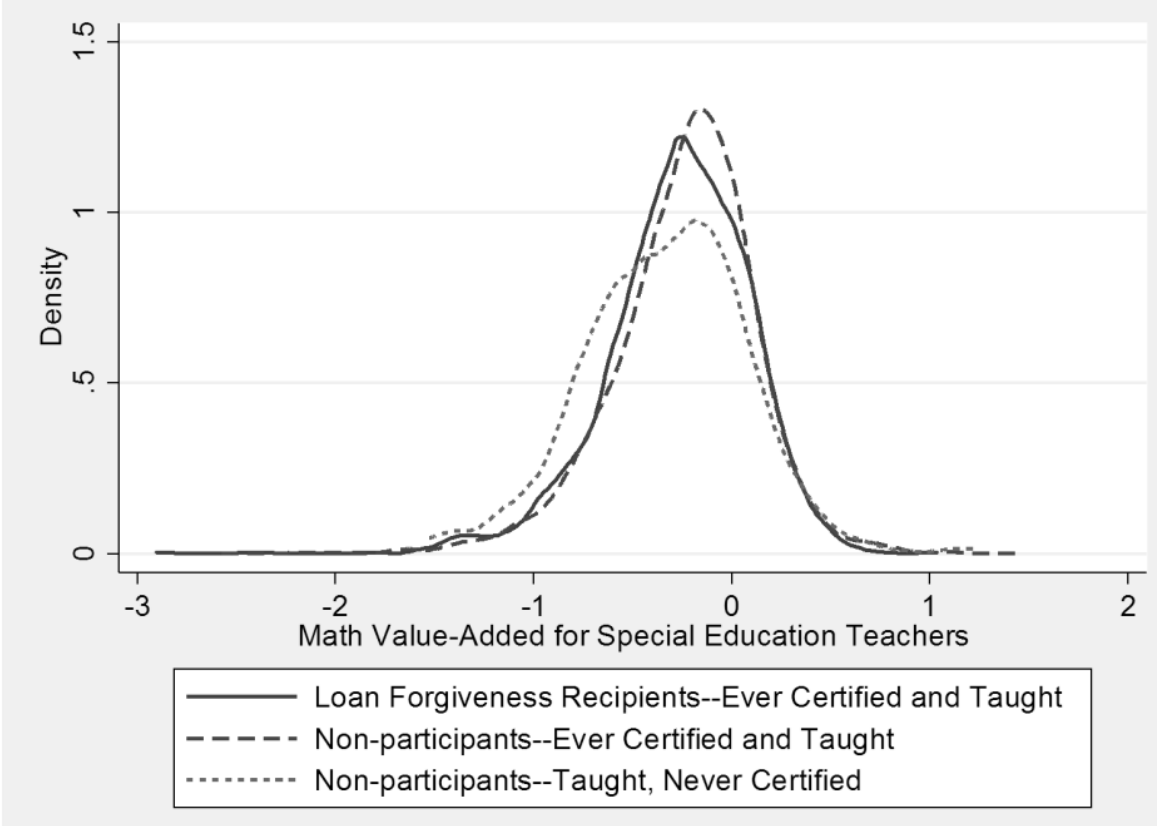

Figure 4C: Kernel Density Plot of Reading Value-Added Distribution by Loan Forgiveness Receipt - Special Education Teachers

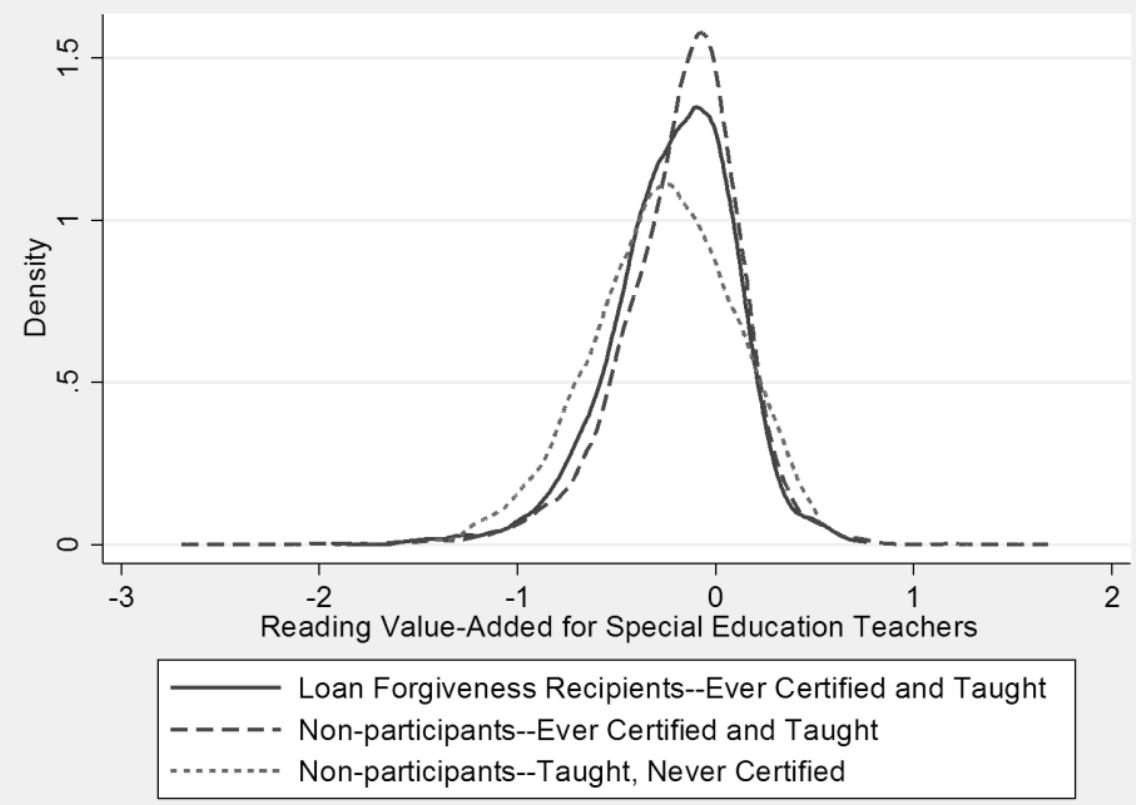


Table 1: Designated Critical Teacher Shortage Areas, 1984/1985 - 2009/2010

\begin{tabular}{|c|c|c|c|c|c|c|c|c|c|c|c|c|c|c|}
\hline & Math & Science & $\begin{array}{l}\text { Middle } \\
\& \text { High } \\
\text { Science }\end{array}$ & $\begin{array}{l}\text { Middle } \\
\text { \& High } \\
\text { Math }\end{array}$ & $\begin{array}{c}\text { Speech } \\
\text { Ther- } \\
\text { apy }\end{array}$ & $\begin{array}{l}\text { Emo- } \\
\text { tionally } \\
\text { Handi- } \\
\text { capped }\end{array}$ & $\begin{array}{c}\text { ESE } \\
\text { ("Han- } \\
\text { dicap- } \\
\text { ped") }\end{array}$ & $\begin{array}{c}\text { ESE } \\
\text { (Special } \\
\text { Ed.) }\end{array}$ & $\begin{array}{c}\text { Foreign } \\
\text { Lang- } \\
\text { uages }\end{array}$ & English & $\begin{array}{l}\text { Middle } \\
\& \text { High } \\
\text { English }\end{array}$ & $\begin{array}{c}\text { Read- } \\
\text { ing }\end{array}$ & ESOL & $\begin{array}{l}\text { Tech. } \\
\text { Ed./ } \\
\text { Ind. } \\
\text { Arts }\end{array}$ \\
\hline 1984-1985 & $x$ & $x$ & & & $x$ & $x$ & & & $x$ & & & & & $x$ \\
\hline 1985-1986 & $x$ & $x$ & & & & $x$ & & & $x$ & $x$ & & & & \\
\hline 1986-1987 & $x$ & $x$ & & & & $x$ & & & $x$ & $x$ & & & & \\
\hline $1987-1988$ & $x$ & $x$ & & & & $x$ & & & $x$ & & & & & \\
\hline 1988-1989 & $x$ & $x$ & & & & $x$ & & & $x$ & $x$ & & & & \\
\hline $1989-1990$ & & & $x$ & $x$ & & & $x$ & & $x$ & & $x$ & & & \\
\hline 1990-1991 & & & $x$ & $x$ & & & $x$ & & $x$ & & $x$ & & & \\
\hline 1991-1992 & & & $x$ & $x$ & & & $x$ & & $x$ & & $x$ & & & \\
\hline 1992-1993 & & & $x$ & $x$ & & & & $x$ & & & & & $x$ & \\
\hline 1993-1994 & & & & & & & & $x$ & & & & & $x$ & \\
\hline 1994-1995 & & & & & & & & $x$ & & & & & $x$ & \\
\hline 1995-1996 & & & & & & & & $x$ & & & & & $x$ & \\
\hline 1996-1997 & & & & & & & & $x$ & & & & & $x$ & $x$ \\
\hline 1997-1998 & & & & & & & & $x$ & & & & & $x$ & $x$ \\
\hline 1998-1999 & & & & & & & & $x$ & & & & & $x$ & $x$ \\
\hline 1999-2000 & & & & & & & & $x$ & & & & & $x$ & $x$ \\
\hline $2000-2001$ & & & $x$ & $x$ & & & & $x$ & & & & & $x$ & $x$ \\
\hline 2001-2002 & & & $x$ & $x$ & & & & $x$ & $x$ & & & & $x$ & $x$ \\
\hline $2002-2003$ & & & $x$ & $x$ & & & & $x$ & $x$ & & & $x$ & $x$ & $x$ \\
\hline 2003-2004 & & & $x$ & $x$ & & & & $x$ & $x$ & & & $x$ & $x$ & $x$ \\
\hline 2004-2005 & & & $x$ & $x$ & & & & $x$ & $x$ & & & $x$ & $x$ & $x$ \\
\hline $2005-2006$ & & & $x$ & $x$ & & & & $x$ & $x$ & & & $x$ & $x$ & $x$ \\
\hline 2006-2007 & & & $x$ & $x$ & & & & $x$ & $x$ & & & $x$ & $x$ & $x$ \\
\hline $2007-2008$ & & & $x$ & $x$ & & & & $x$ & $x$ & & & $x$ & $x$ & $x$ \\
\hline 2008-2009 & & & $x$ & $x$ & & & & $x$ & $x$ & & $x$ & $x$ & $x$ & $x$ \\
\hline 2009-2010 & & & $x$ & $x$ & & & & $x$ & $x$ & & $x$ & $x$ & $x$ & $x$ \\
\hline
\end{tabular}

Source: Florida Department of Education, Critical Teacher Shortage Areas (various years). In School Year 1992-1993, Middle and High Level Science was specifically labeled Middle and

High Level Physical Sciences. In all years where Industrial Arts appears, except 1984-1985, it appears as Technology Education/Industrial Arts. Thus, they are listed as a combined area.

School psychologists were also designated as a shortage area from 2002/2003 through 2007/2008, but are omitted because they are not instructional personnel. 
Table 2: Mean and Standard Deviation of Characteristics of Non-Recipients, Teachers Eligible for Loan Forgiveness, Loan Forgiveness Recipients, and Bonus Recipients

\begin{tabular}{|c|c|c|c|c|}
\hline & $\begin{array}{c}\text { Non- } \\
\text { Recipients }\end{array}$ & $\begin{array}{c}\text { Teachers } \\
\text { Eligible for } \\
\text { Loan } \\
\text { Forgiveness } \\
\end{array}$ & $\begin{array}{c}\text { Loan } \\
\text { Forgiveness } \\
\text { Recipients }\end{array}$ & $\begin{array}{c}\text { Bonus } \\
\text { Recipients }\end{array}$ \\
\hline Female & $0.78(0.41)$ & $0.75(0.43)$ & $0.82(0.38)$ & $0.77(0.42)$ \\
\hline Black & $0.14(0.35)$ & $0.12(0.33)$ & $0.17(0.38)$ & $0.11(0.31)$ \\
\hline Hispanic & $0.10(0.30)$ & $0.10(0.30)$ & $0.12(0.33)$ & $0.03(0.16)$ \\
\hline Other Non-White & $0.01(0.10)$ & $0.01(0.12)$ & $0.01(0.12)$ & $0.01(0.08)$ \\
\hline $\begin{array}{l}\text { Experience in Florida Public } \\
\text { Schools }\end{array}$ & $10.26(9.22)$ & $10.12(8.93)$ & $5.09(4.60)$ & $14.79(9.07)$ \\
\hline Exited Florida Public Schools & $0.13(0.34)$ & $0.12(0.33)$ & $0.13(0.34)$ & $0.08(0.27)$ \\
\hline $\begin{array}{l}\text { Amount of Loan Forgiveness } \\
\text { Received (\$) }\end{array}$ & & & $\begin{array}{l}1,203.35 \\
(1272.88) \\
\end{array}$ & \\
\hline $\begin{array}{l}\text { Amount of Bonus Payment } \\
\text { Received (\$) }\end{array}$ & & & & $\begin{array}{l}1,197.53 \\
(184.67) \\
\end{array}$ \\
\hline Certified in Middle/HS Math & $0.08(0.27)$ & $0.27(0.44)$ & $0.13(0.34)$ & $0.23(0.42)$ \\
\hline Certified in Middle/HS Science & $0.06(0.25)$ & $0.23(0.42)$ & $0.11(0.31)$ & $0.21(0.41)$ \\
\hline Certified in Foreign Languages & $0.03(0.17)$ & $0.08(0.27)$ & $0.02(0.15)$ & $0.06(0.23)$ \\
\hline Certified in Reading & $0.03(0.16)$ & $0.01(0.12)$ & $0.03(0.16)$ & $0.01(0.12)$ \\
\hline Certified in Middle/HS English & $0.11(0.31)$ & $0.04(0.21)$ & $0.04(0.21)$ & $0.05(0.22)$ \\
\hline Certified in Special Education & $0.15(0.35)$ & $0.45(0.50)$ & $0.72(0.45)$ & $0.40(0.49)$ \\
\hline Certified in ESOL & $0.04(0.20)$ & $0.03(0.18)$ & $0.07(0.26)$ & $0.01(0.12)$ \\
\hline Certified in Industrial Arts & $0.01(0.08)$ & $0.00(0.06)$ & $0.01(0.09)$ & $0.01(0.11)$ \\
\hline Taught Middle/HS Math & $0.09(0.29)$ & $0.30(0.46)$ & $0.23(0.42)$ & $0.28(0.45)$ \\
\hline Taught Middle/HS Science & $0.09(0.29)$ & $0.25(0.44)$ & $0.21(0.41)$ & $0.26(0.44)$ \\
\hline Taught Foreign Languages & $0.02(0.15)$ & $0.07(0.25)$ & $0.01(0.12)$ & $0.06(0.23)$ \\
\hline Taught Reading & $0.04(0.20)$ & $0.04(0.19)$ & $0.06(0.25)$ & $0.03(0.17)$ \\
\hline Taught Middle/HS English & $0.11(0.31)$ & $0.09(0.29)$ & $0.15(0.36)$ & $0.09(0.28)$ \\
\hline Taught Special Education & $0.11(0.32)$ & $0.34(0.47)$ & $0.53(0.50)$ & $0.36(0.48)$ \\
\hline Taught ESOL & $0.08(0.27)$ & $0.03(0.17)$ & $0.05(0.22)$ & $0.01(0.10)$ \\
\hline $\begin{array}{l}\text { Class average disciplinary incidents } \\
\text { per student }\end{array}$ & $0.11(0.44)$ & $0.17(0.60)$ & $0.18(0.71)$ & $0.22(0.65)$ \\
\hline $\begin{array}{l}\text { Class average proportion Black } \\
\text { students }\end{array}$ & $0.24(0.25)$ & $0.25(0.25)$ & $0.28(0.27)$ & $0.24(0.23)$ \\
\hline $\begin{array}{l}\text { Class average proportion Hispanic } \\
\text { students }\end{array}$ & $0.24(0.26)$ & $0.22(0.24)$ & $0.25(0.26)$ & $0.11(0.14)$ \\
\hline $\begin{array}{l}\text { Class average free/reduced-price } \\
\text { lunch students }\end{array}$ & $0.53(0.29)$ & $0.52(0.28)$ & $0.62(0.26)$ & $0.45(0.28)$ \\
\hline Teacher Value-Added in Math & $-0.02(0.33)$ & $-0.10(0.36)$ & $-0.17(0.40)$ & $-0.11(0.35)$ \\
\hline Teacher Value-Added in Reading & $-0.01(0.28)$ & $-0.11(0.33)$ & $-0.13(0.32)$ & $-0.12(0.33)$ \\
\hline $\begin{array}{l}\text { Number of Teacher-Year } \\
\text { Observations }\end{array}$ & 2418181 & 726458 & 54949 & 94833 \\
\hline
\end{tabular}

Note: Eligible Teachers are those who were certified and taught in a critical need area in the same year. Means of time varying variables are computed across all years in which a teacher is observed teaching. 
Table 3: Percentage Distribution of Years of Experience Teaching in Florida Public Schools at Time of Initial Loan Forgiveness Award

\begin{tabular}{|c|c|}
\hline $\begin{array}{c}\text { Years of } \\
\text { Experience }\end{array}$ & $\begin{array}{c}\text { Loan } \\
\text { Forgiveness Initial } \\
\text { Award }\end{array}$ \\
\hline 0 & 6.00 \\
\hline 1 & 62.31 \\
\hline 2 & 14.85 \\
\hline 3 & 5.94 \\
\hline 4 & 3.60 \\
\hline 5 & 1.79 \\
\hline 6 & 1.35 \\
\hline 7 & 1.01 \\
\hline 8 & 0.66 \\
\hline 9 & 0.51 \\
\hline 10 & 0.44 \\
\hline 11 & 0.40 \\
\hline 12 & 0.29 \\
\hline 13 & 0.22 \\
\hline 14 & 0.09 \\
\hline 15 & 0.04 \\
\hline More than 15 & 0.51 \\
\hline & \\
\hline Total & 100.00 \\
\hline
\end{tabular}


Table 4: Cox Proportional Hazard Estimates of the Probability of Exit from the Florida Public School System

\begin{tabular}{|c|c|c|c|c|}
\hline Independent Variable & Model 1 & Model 2 & Model 3 & Model 4 \\
\hline $\begin{array}{l}\text { Ever Eligible in MS/HS Science x MS/HS } \\
\text { Science a Designated Area }\end{array}$ & $\begin{array}{l}0.911 * * \\
(0.029)\end{array}$ & $\begin{array}{l}0.901 * * \\
(0.030)\end{array}$ & $\begin{array}{l}0.898 * * \\
(0.031)\end{array}$ & $\begin{array}{l}0.896^{* *} \\
(0.031)\end{array}$ \\
\hline $\begin{array}{l}\text { Ever Eligible in MS/HS Math x MS/HS } \\
\text { Math a Designated Area }\end{array}$ & $\begin{array}{l}0.896 * * \\
(0.029)\end{array}$ & $\begin{array}{l}0.898 * * \\
(0.030)\end{array}$ & $\begin{array}{l}0.898 * * \\
(0.031)\end{array}$ & $\begin{array}{l}0.898 * * \\
(0.031)\end{array}$ \\
\hline $\begin{array}{l}\text { Ever Eligible in Special Ed/Gifted x Special } \\
\text { Ed/Gifted a Designated Area }\end{array}$ & $\begin{array}{c}0.975 \\
(0.029)\end{array}$ & $\begin{array}{c}0.980 \\
(0.030)\end{array}$ & $\begin{array}{c}0.981 \\
(0.031)\end{array}$ & $\begin{array}{c}0.972 \\
(0.031)\end{array}$ \\
\hline $\begin{array}{l}\text { Ever Eligible in Foreign Languages x } \\
\text { Foreign Languages a Designated Area }\end{array}$ & $\begin{array}{l}0.878^{* *} \\
(0.046)\end{array}$ & $\begin{array}{l}0.865 * * \\
(0.047)\end{array}$ & $\begin{array}{l}0.881^{* *} \\
(0.050)\end{array}$ & $\begin{array}{l}0.885 * * \\
(0.050)\end{array}$ \\
\hline $\begin{array}{l}\text { Ever Eligible in MS/HS English x MS/HS } \\
\text { English a Designated Area }\end{array}$ & $\begin{array}{c}1.053 \\
(0.038)\end{array}$ & $\begin{array}{c}1.037 \\
(0.039)\end{array}$ & $\begin{array}{c}1.026 \\
(0.040)\end{array}$ & $\begin{array}{c}1.022 \\
(0.040)\end{array}$ \\
\hline $\begin{array}{l}\text { Ever Eligible in Reading x MS/HS Reading } \\
\text { a Designated Area }\end{array}$ & $\begin{array}{c}1.099 \\
(0.099)\end{array}$ & $\begin{array}{l}1.105 \\
(0.104)\end{array}$ & $\begin{array}{l}1.105 \\
(0.107)\end{array}$ & $\begin{array}{c}1.099 \\
(0.107)\end{array}$ \\
\hline $\begin{array}{l}\text { Ever Eligible in ESOL x ESOL a } \\
\text { Designated Area }\end{array}$ & $\begin{array}{l}0.726 * * \\
(0.049)\end{array}$ & $\begin{array}{l}0.723 * * \\
(0.051)\end{array}$ & $\begin{array}{l}0.723 * * \\
(0.052)\end{array}$ & $\begin{array}{l}0.729 * * \\
(0.053)\end{array}$ \\
\hline $\begin{array}{l}\text { Taught Certified and Taught Covered } \\
\text { Subject x MS/HS Teacher x Year } 1999\end{array}$ & $\begin{array}{l}0.678 * * \\
(0.066)\end{array}$ & $\begin{array}{l}0.680 * * \\
(0.068)\end{array}$ & $\begin{array}{l}0.681^{* *} \\
(0.073)\end{array}$ & $\begin{array}{l}0.675^{* *} \\
(0.072)\end{array}$ \\
\hline $\begin{array}{l}\text { Controls for Ever Taught and Certified in } \\
\text { Each Ever-Designated Area }\end{array}$ & $\sqrt{ }$ & $\sqrt{ }$ & $\sqrt{ }$ & $\sqrt{ }$ \\
\hline $\begin{array}{l}\text { Controls for each Subject Designated a } \\
\text { Critical Shortage Area }\end{array}$ & $\sqrt{ }$ & $\sqrt{ }$ & $\sqrt{ }$ & $\sqrt{ }$ \\
\hline $\begin{array}{l}\text { Controls for Teacher Base Salary and } \\
\text { District Fixed Effects }\end{array}$ & $\sqrt{ }$ & $\sqrt{ }$ & $\sqrt{ }$ & $\sqrt{ }$ \\
\hline Controls for Teacher Demographics & & $\sqrt{ }$ & $\sqrt{ }$ & $\sqrt{ }$ \\
\hline $\begin{array}{l}\text { Controls for Teacher Experience and } \\
\text { Advanced Degree Attainment }\end{array}$ & & & $\sqrt{ }$ & $\sqrt{ }$ \\
\hline $\begin{array}{l}\text { Controls for Courses Taught and } \\
\text { Classroom-level Student Characteristics }\end{array}$ & & & & $\sqrt{ }$ \\
\hline Number of Observations & 553,113 & 518,342 & 495,839 & 490,915 \\
\hline Number of Teachers & 124,058 & 117,042 & 114,825 & 114,400 \\
\hline Log Likelihood & $-704,727$ & $-655,937$ & $-612,521$ & $-603,015$ \\
\hline
\end{tabular}

Note: Standard errors are in parentheses. Teacher demographics include gender and race/ethnicity.

Experience/degree attainment controls include indicators for 0, 1, 2, 3, 4-9, 20-29, 30-39, 40+ years of experience and an indicator for possession of an advanced degree. Classroom characteristics include class size, average number of disciplinary incidents in the prior year per student, proportion of students receiving free/reduced-price lunch, proportion of students who are black, and proportion of students who are Hispanic. All models include year effects. *Significant at the 10 percent level. **Significant at the 5 percent level. 
Table 5: Cox Proportional Hazard Estimates of the Probability of Exit from the Florida Public School System, Allowing for Effects of Loan Forgiveness to Vary by Size of Payout

\begin{tabular}{|c|c|c|c|c|}
\hline Independent Variable & Model 1 & Model 2 & Model 3 & Model 4 \\
\hline $\begin{array}{l}\text { Ever Eligible in MS/HS Science x MS/HS } \\
\text { Science a Designated Area }\end{array}$ & $\begin{array}{l}0.923 * * \\
(0.030)\end{array}$ & $\begin{array}{l}0.910 * * \\
(0.031)\end{array}$ & $\begin{array}{l}0.908 * * \\
(0.031)\end{array}$ & $\begin{array}{l}0.906^{* *} \\
(0.031)\end{array}$ \\
\hline $\begin{array}{l}\text { Ever Eligible in MS/HS Math x MS/HS } \\
\text { Math a Designated Area }\end{array}$ & $\begin{array}{l}0.905^{* *} \\
(0.029)\end{array}$ & $\begin{array}{l}0.905^{* *} \\
(0.030)\end{array}$ & $\begin{array}{l}0.905^{* *} \\
(0.031)\end{array}$ & $\begin{array}{l}0.905^{* *} \\
(0.031)\end{array}$ \\
\hline $\begin{array}{l}\text { Ever Eligible in Special Ed/Gifted x Special } \\
\text { Ed/Gifted a Designated Area [Low] }\end{array}$ & $\begin{array}{c}0.995 \\
(0.030)\end{array}$ & $\begin{array}{c}0.998 \\
(0.031)\end{array}$ & $\begin{array}{c}0.998 \\
(0.032)\end{array}$ & $\begin{array}{c}0.990 \\
(0.032)\end{array}$ \\
\hline $\begin{array}{l}\text { Ever Eligible in Special Ed/Gifted x Special } \\
\text { Ed/Gifted a Designated Area [High] }\end{array}$ & $\begin{array}{l}0.877 * * \\
(0.036)\end{array}$ & $\begin{array}{l}0.898 * * \\
(0.037)\end{array}$ & $\begin{array}{l}0.899 * * \\
(0.038)\end{array}$ & $\begin{array}{l}0.891 * * \\
(0.038)\end{array}$ \\
\hline $\begin{array}{l}\text { Ever Eligible in Foreign Languages } x \\
\text { Foreign Languages a Designated Area }\end{array}$ & $\begin{array}{l}0.887 * * \\
(0.047)\end{array}$ & $\begin{array}{l}0.872 * * \\
(0.048)\end{array}$ & $\begin{array}{l}0.887 * * \\
(0.050)\end{array}$ & $\begin{array}{l}0.891 * * \\
(0.051)\end{array}$ \\
\hline $\begin{array}{l}\text { Ever Eligible in MS/HS English x MS/HS } \\
\text { English a Designated Area }\end{array}$ & $\begin{array}{c}1.055 \\
(0.039)\end{array}$ & $\begin{array}{c}1.039 \\
(0.039)\end{array}$ & $\begin{array}{c}1.028 \\
(0.040)\end{array}$ & $\begin{array}{c}1.024 \\
(0.040)\end{array}$ \\
\hline $\begin{array}{l}\text { Ever Eligible in Reading x MS/HS Reading } \\
\text { a Designated Area }\end{array}$ & $\begin{array}{c}1.095 \\
(0.099)\end{array}$ & $\begin{array}{c}1.101 \\
(0.104)\end{array}$ & $\begin{array}{c}1.101 \\
(0.107)\end{array}$ & $\begin{array}{c}1.095 \\
(0.106)\end{array}$ \\
\hline $\begin{array}{l}\text { Ever Eligible in ESOL } \times \text { ESOL a } \\
\text { Designated Area [Low] }\end{array}$ & $\begin{array}{l}0.747 * * \\
(0.051)\end{array}$ & $\begin{array}{l}0.743 * * \\
(0.053)\end{array}$ & $\begin{array}{l}0.747 * * \\
(0.055)\end{array}$ & $\begin{array}{l}0.755^{* *} \\
(0.056)\end{array}$ \\
\hline $\begin{array}{l}\text { Ever Eligible in ESOL x ESOL a } \\
\text { Designated Area [High] }\end{array}$ & $\begin{array}{l}0.604 * * \\
(0.063)\end{array}$ & $\begin{array}{l}0.609 * * \\
(0.065)\end{array}$ & $\begin{array}{l}0.582 * * \\
(0.065)\end{array}$ & $\begin{array}{l}0.579 * * \\
(0.065)\end{array}$ \\
\hline $\begin{array}{l}\text { Taught Certified and Taught Covered } \\
\text { Subject x MS/HS Teacher x Year } 1999\end{array}$ & $\begin{array}{l}0.646^{* * *} \\
(0.064)\end{array}$ & $\begin{array}{l}0.654 * * \\
(0.066)\end{array}$ & $\begin{array}{l}0.654 * * \\
(0.070)\end{array}$ & $\begin{array}{l}0.648 * * \\
(0.070)\end{array}$ \\
\hline $\begin{array}{l}\text { Controls for Ever Taught and Certified in } \\
\text { Each Ever-Designated Area }\end{array}$ & $\sqrt{ }$ & $\sqrt{ }$ & $\sqrt{ }$ & $\sqrt{ }$ \\
\hline $\begin{array}{l}\text { Controls for each Subject Designated a } \\
\text { Critical Shortage Area }\end{array}$ & $\sqrt{ }$ & $\sqrt{ }$ & $\sqrt{ }$ & $\sqrt{ }$ \\
\hline $\begin{array}{l}\text { Controls for Teacher Base Salary and } \\
\text { District Fixed Effects }\end{array}$ & $\sqrt{ }$ & $\sqrt{ }$ & $\sqrt{ }$ & $\sqrt{ }$ \\
\hline Controls for Teacher Demographics & & $\sqrt{ }$ & $\sqrt{ }$ & $\sqrt{ }$ \\
\hline $\begin{array}{l}\text { Controls for Teacher Experience and } \\
\text { Advanced Degree Attainment }\end{array}$ & & & $\sqrt{ }$ & $\sqrt{ }$ \\
\hline $\begin{array}{l}\text { Controls for Courses Taught and } \\
\text { Classroom-level Student Characteristics }\end{array}$ & & & & $\sqrt{ }$ \\
\hline Number of Observations & 553,113 & 518,342 & 495,839 & 490,915 \\
\hline Number of Teachers & 124,058 & 117,042 & 114,825 & 114,400 \\
\hline Log Likelihood & $-704,717$ & $-655,929$ & $-612,513$ & $-603,007$ \\
\hline
\end{tabular}

Note: "High" and "Low" refer to high and low average payout periods (pre-2001/2002 and 2001/2002 and later). See also notes from Table 4. 
Table 6: Cox Proportional Hazard Estimates of the Probability of Exit from the Florida Public School System Sample Limited to Cohorts of New Teachers +/- 2 Years around Change in Critical Shortage Area Designation

\begin{tabular}{|c|c|c|c|c|c|}
\hline \multirow{3}{*}{ Independent Variable } & \multicolumn{5}{|c|}{ Subject Area and Teacher Cohorts } \\
\hline & $\begin{array}{l}\text { Middle \& } \\
\text { High Math }\end{array}$ & $\begin{array}{l}\text { Middle \& } \\
\text { High } \\
\text { Science }\end{array}$ & $\begin{array}{c}\text { Foreign } \\
\text { Language }\end{array}$ & $\begin{array}{c}\text { Middle \& } \\
\text { High English }\end{array}$ & Reading \\
\hline & \multicolumn{2}{|c|}{$\begin{array}{c}1998 / 1999- \\
2001 / 2002\end{array}$} & $\begin{array}{l}1999 / 2000- \\
2002 / 2003\end{array}$ & $\begin{array}{l}2006 / 2007- \\
2009 / 2010\end{array}$ & $\begin{array}{l}2000 / 2001- \\
2003 / 2004\end{array}$ \\
\hline $\begin{array}{l}\text { Ever Eligible in Subject x } \\
\text { Subject a Designated Area }\end{array}$ & $\begin{array}{c}0.880 * \\
(0.066)\end{array}$ & $\begin{array}{l}0.825^{* *} \\
(0.062)\end{array}$ & $\begin{array}{c}0.797 * \\
(0.101)\end{array}$ & $\begin{array}{c}0.961 \\
(0.061)\end{array}$ & $\begin{array}{c}0.985 \\
(0.192)\end{array}$ \\
\hline $\begin{array}{l}\text { Controls for Ever Taught and } \\
\text { Certified in Each Ever- } \\
\text { Designated Area }\end{array}$ & \multicolumn{2}{|c|}{$\sqrt{ }$} & $\sqrt{ }$ & $\sqrt{ }$ & $\sqrt{ }$ \\
\hline $\begin{array}{l}\text { Controls for each Subject } \\
\text { Designated a Critical } \\
\text { Shortage Area }\end{array}$ & \multicolumn{2}{|c|}{$\sqrt{ }$} & $\sqrt{ }$ & $\sqrt{ }$ & $\sqrt{ }$ \\
\hline $\begin{array}{l}\text { Controls for Teacher Base } \\
\text { Salary and District Fixed } \\
\text { Effects }\end{array}$ & \multicolumn{2}{|c|}{$\sqrt{ }$} & $\sqrt{ }$ & $\sqrt{ }$ & $\sqrt{ }$ \\
\hline Number of Observations & \multicolumn{2}{|c|}{143,823} & 133,719 & 96,642 & 133,608 \\
\hline Number of Teachers & \multicolumn{2}{|c|}{24,144} & 23,656 & 29,595 & 25,061 \\
\hline Log Likelihood & \multicolumn{2}{|c|}{$-160,447$} & $-147,125$ & $-113,921$ & $-151,183$ \\
\hline
\end{tabular}

Note: See notes for Table 4. 